\title{
The Extra-floral Nectaries of Hevea brasiliensis, Müll.- Arg. (the Para Rubber Tree), an Example of Bud-Scales ${ }^{1}$ serving as Nectaries.
}

BY

\author{
JOHN PARKIN, M.A., \\ Trinity College, Cambridge.
}

\section{With Plate XVI.}

$W^{1}$

HILE engaged in economic work on india-rubber in Ceylon during I898-9, the Para Rubber Tree (Hevea brasiliensis) ${ }^{2}$ was constantly under my observation, and peculiar nectaries occupying the position of budscales on its young shoots attracted my attention. Less conspicuous nectaries also occur on the foliage leaves proper. Though these latter are incidentally mentioned by systematists, the bud-scales generally, as well as their nectariferous nature, appear to have escaped their notice. This is not surprising, for the adult tree only puts forth fresh foliage annually, and the bud-scales being caducous, are merely evident while the shoots are in the immature condition; thus, unless the tree be examined during the short period of leaf-renewal, no bud-scales would be seen.

In the account of the genus Hevea in Martius' Flora of Brazil ${ }^{3}$, the nectaries of the foliage leaves are mentioned, but no reference is made to the bud-scales. Delpino ${ }^{4}$ in his elaborate work on extra-floral nectaries dismisses this genus in a few words, referring apparently only to the nectaries of the foliage leaves.

In a recent paper by Huber ${ }^{5}$ on the periodicity in growth of Hevea

1 The term ' bud-scale' is here used in the sense of a reduced leaf-structure situated on the shoot below the true foliage leaves. The author does not necessarily wish to imply that such structures in Hevea serve or have ever served as protective coverings to the bud.

2 Introduced into Ceylon in 1876.

${ }^{3}$ Martius, Flora brasiliensis, vol. xi, pars. II, I 873 . On p. 298 the genus (nine species including H. brasiliensis) is described as having 'petioli communes apice supra glanduligeri.'

4 Delpino, Mem. Accad. Bologna, viii, 1887, p. 635. In giving examples of extra-floral nectaries in the Euphorbiaceae he refers to Hevea as follows: ' 8 specie di Hevea (petioli ima basi patellari-glanduligeri).'

5 Huber, Bot. Centralb. 1xxvi, I898, pp. 259-64.

[Annals of Botany, Vo1. XVIII. No. LXX. April, 1904.]

Q.2 
brasiliensis the bud-scales are just mentioned, but their nectariferous nature is not pointed out.

The description to follow is the result partly of observations made while resident at the Royal Botanic Gardens, Peradeniya, Ceylon, and partly of the examination of some spirit-preserved young shoots from adult trees brought back to England. The following account does not claim to be at all exhaustive. The object of this paper is chiefly to bring to notice a somewhat peculiar type of extra-floral nectary.

Morphology of the shoot. The adult trees at Peradeniya shed their leaves early in the year and remain bare for some days before the new foliage appears. On February I6, I 899, the new shoots had almost gained their full length, but their foliage leaves were still very immature. At this stage of growth the bud-scales are fully developed and their nectaries active. On the leaves attaining maturity these structures shrivel and drop off. According to Huber ${ }^{1}$ the adult trees in their natural habitat, the Amazon valley, produce likewise only one crop of leaves in the year, but the time they are bare is about June; hence the trees in Ceylon appear to have changed the time of the annual renewal of their foliage. This may be due to climate. The early months of the year constitute a moderately marked dry season in that part of Ceylon where Peradeniya is situated, and dryness is considered to have a direct bearing on leaf-fall. Yet on this idea the Hevea trees at Peradeniya ought not to burst into fresh leaf till about April, when the rains of the little monsoon commence: as it is they renew their foliage about the driest time of the year, while they cast off the old in January, a wetter and cooler month than either February or March.

Though mature trees produce only one set of leaves during the year, young trees-saplings-put forth several, showing a periodicity, which has been described by Huber ${ }^{2}$. Such saplings may produce fresh shoots about every month.

My attention was first called to the nectariferous bud-scales by noticing one day insects busy on the young shoots of some saplings growing in a plot. At a short distance away they looked as if they were devouring the immature foliage, leaving behind the stumps of the petioles, but on closer inspection I saw that they were a hairy kind of ant (?) imbibing the honey secreted by special foliar organs situated on the lower part of the shoot. Owing to the internodes between these structures having lengthened considerably, the general impression conveyed a little distance away was that of short petioles with the foliaceous part nibbled off. The true foliage leaves, however, were quite intact on the upper part of the shoot with their laminas as yet feebly developed. My first observations were made on these saplings, as I had to wait till the 
proper time of the year to see if the young shoots of mature trees likewise possessed these nectariferous scales. Such was found to be the case.

The foliage leaves of Hevea brasiliensis are not evenly distributed along the whole length of the shoot, but are crowded together on the upper portion. The stretch of stem, which in the mature shoot appears to be a long internode below the foliage leaves, is really composed of several, the nodes of which were occupied in the young state by the nectariferous scales. That is to say, the internodes between the upper nectariferous scales have increased considerably in length-this is especially well seen in saplings. The leaf is trifoliate with a long petiole. The leaflets are large and lanceolate in shape, and are joined to the apex of the petiole by very short stalks (Plate XVI. Fig. 3). As a rule the length of the petiole and the size of the leaflets of a shoot decrease from the base upwards. For example, the petiole and leaflet of the lowest leaf may have a length of $30 \mathrm{~cm}$. and $23 \mathrm{~cm}$. respectively; whereas these measurements for the uppermost leaf may be only $3.5 \mathrm{~cm}$. and $4.5 \mathrm{~cm}$. respectively. The direction of the petioles is such that their laminas tend to be in one plane, and thus do not overshadow one another. The number of foliage leaves to a shoot varies, but is commonly twelve. They as well as the scales have a three-eighth arrangement on the stem-axis.

The nectary of the foliage leaf is situated on the upper surface just at the point of union of the leaflets with the petiole (Fig. $3 n$ ). It may consist of either three contiguous saucer-shaped glands, one corresponding to each leaflet, or of only two of these, as in the figure, or it may assume the form of an irregular depression due to their fusion. In any case, they are not prominent structures, and do not differ as a rule in colour from the surrounding surface.

The bud-scales permit of division into two categories, viz. (I) the basal scales which are very small, non-nectariferous, and usually few in number; (2) the upper scales which are conspicuous, nectariferous, and numerous. Both kinds of scales as well as the foliage leaves possess each a pair of insignificant stipules (Figs. I and $2 s t$ ).

The basal non-nectariferous bud-scales. In the spirit material brought home for examination two types of young shoots could be distinguished, viz. those which had very few-one to three-non-nectariferous scales, and those possessing a great number, twenty or so. A drawing of each kind of shoot is shown in Figs. I and 2 respectively. A few shoots were intermediate in this respect, having several non-nectariferous scales, but not such an imbrication of them as represented in Fig. $2 s$. No mention is made in my Ceylon notes of any large number of these basal scales having been noticed, but the shoots are referred to as possessing not 
more than two or three each. Whether or not the possession of a large number of these scales be a common feature of young Hevea shoots cannot well be decided from the few examined, but the supposition is that such a shoot as the one shown in Fig. 2 is exceptional, and that as a rule only two or three non-nectariferous scales occur.

The nectariferous bud-scales. These vary considerably in number. The average for twenty-two shoots of adult trees examined was seven, ranging from five to twelve. The shoot from which Fig. I was drawn possessed eight, while that of Fig. 2 was exceptional in having twelve. Naturally, only part can be represented in the drawings. The lower nectariferous scales are small and short. The middle ones are usually the largest and possess the best developed nectaries, while the upper ones, though quite as long, are not so thick, and have the honey-secreting part reduced in extent; in fact in the uppermost one of all this part may be restricted to the apex, or perhaps even absent. The internodes increase in length as a rule from the base upwards; thus the lower nectariferous scales are near together, while the upper ones are some distance apart.

The inflorescences are borne in the axils of the nectariferous scales as well as in those of the lower foliage leaves (Figs. I and $2 f$ ).

Sapling. The young shoots of saplings resemble in most respects those of the adult trees, but being longer the internodes between the middle and upper nectariferous scales are more marked. From an examination of thirty-eight young sapling shoots the following numbers were obtained:-

non-nectariferous basal scales ranged in number from $0-3$, aver. $I$.

nectariferous scales

foliage leaves-average 10.

$4-7, \quad, 5$.

Nine of these thirty-eight young shoots possessed each an arrested leaf between the nectariferous scales and the foliage leaves proper. This bore three leaflets well defined but quite small, while the nectariferous scales have mere points to indicate the remains of the leaflets. The nectary appeared to be absent ${ }^{1}$. This vestigial leaf did not persist, but withered and fell off with the scales.

Seedling. In germination the two cotyledons remain in the testa in the soil, so that what looks like a hypocotyl is really the epicotyl; it is quite long, $25 \mathrm{~cm}$. or so in length. The first two foliage leaves formed quit the stem about the same level, and are similar in shape to those of older plants. Then comes an internode of about $3 \mathrm{~cm}$., followed by two more foliage leaves situated at nearly the same level on the stem and alternating with the first pair; sometimes there may be only one

${ }_{1}$ Not microscopically examined-might possibly possess a trace of glandular tissue invisible to the naked eye. 
leaf, or even three at this point. Occasionally the first pair of leaves may be vestigial, or only one of them fully developed.

If the plumule be fatally injured then the bud in the axil of one of the cotyledons develops into a shoot, bearing first three to four reduced leaves apparently without nectaries, before the true foliage leaves appear; sometimes the buds in both axils so sprout. The shoot arising from the axillary bud of the cotyledon simulates that derived from the plumule, but in the one case the length of stem produced before the foliage leaves are emitted is really composed of several internodes, the nodes being occupied by inconspicuous scale-leaves; while in the other it consists of one internode only, the epicotyl.

Unfortunately my notes do not connect the seedling with the saplingstage, so as to see when the nectariferous scales first arise. This is probably at the second period of foliation. They apparently do not appear in the seedling, but rather later in the development of the plant.

Structure of the individual bud-scales. The structure of the nonnectariferous scales requires little description. A glance at Fig. $4 s$, shows their size and shape. They are each accompanied by a pair of lateral bodies-stipules. In the mature or sprouting bud they are brown dead objects.

The nectariferous scales are fairly long, often bent structures and somewhat circular in transverse section; they project from the stem at right angles or with a downward inclination. Each bears at its apex three minute points, the sole remains of the leaflets. Their upper convex surface is covered with yellow honey-secreting tissue, and has often a median longitudinal groove. In the lower and middle scales the whole length of the upper surface is glandular. In the upper scales the glandular portion tends to recede from the proximal part, and in the uppermost one it is confined to the apex (Fig. $6 n e$ ).

From a structural point of view the nectar-secreting tissue of plants can be divided into two classes ${ }^{1}$, viz. (I) that consisting of small epidermal cells of the usual shape with thin hardly cuticularized outer walls, overlying a mass of closely packed cells full of contents, and secretory in function, and (2) that in which the epidermis itself assumes the form of a secretory epithelium with greatly thickened cuticle. In the first class the nectar reaches the surface by passing through the thin walls, while in the second class it escapes by bursting the cuticle.

The extra-floral nectaries of Hevea brasiliensis present a modification of the second type of structure, in that many of the original epithelial cells become divided in the mature nectary by tangential walls into two or three daughter-cells. That is, in the immature state the epidermis

1 Bonnier, Les nectaires, Etude critique, anatomique et physiologique, Ann. d. Sci. Nat., $6^{\mathrm{e}}$ sér., T. viii, 1879 , p. 96. 
is a simple epithelium, but on approaching maturity it becomes in places two or three layered (Fig. 7). Conspicuous nuclei and much cytoplasm without prominent vacuoles are present in the epithelial cells, as well as in the small cortical cells below. The cuticularized part of the outer wall is quite thick, as is shown in the drawing (Fig. $7 c t$ ).

Examples of extra-floral nectaries with an epithelium divided in places are to be met with in Homalanthus populifera and Clerodendron Bungei ${ }^{1}$; also a regularly two-layered epithelium exists in Prunus avium ${ }^{2}$.

The diagram (Fig. 5) shows the position of the nectar-secreting epithelium in a transverse section of a typical median bud-scale; while that of Fig. 6 represents the epithelium as restricted to the apex in the uppermost scale.

The minute structure of the nectaries of the foliage leaves is similar to that of the scale ones.

General Remarks. This case of Hevea brasiliensis is about the first example cited of bud-scales-cataphyllary leaves-serving as nectaries. The only other instance I have found at all comparable is that mentioned by Reinke ${ }^{3}$. He points out that the bud-scales, as well as the foliage leaves of Prunus avium, have glandular teeth which are honey-secreting. But here the transformation is very partial. The scales are not so modified as to be merely nectaries. Their primary function is still that of bud-protection.

The Euphorbiaceae are rich in examples of plants with extra-floral nectaries. Baillon ${ }^{4}$, in his work on this natural order, enumerates the various types, showing that their situation may be various, such as on the stem, petiole or lamina; and that different organs may be wholly transformed into them, such as stipules and leaflets. Hevea brasiliensis affords a still further type, viz. that of bud-scales serving as nectaries.

Two or three questions suggest themselves as to the origin of these cataphyllary nectaries of Hevea. Are they connected by descent with the petiolar glands, or are they a fresh production of glandular tissue in the evolution of the plant? What is the relationship between the non-nectariferous and nectariferous scales? Have they been derived independently at different periods from foliage leaves, or have the former arisen by further retrogression from the latter? From an identity in structure between the petiolar and scale nectaries and from the situation of the glandular tissue in the uppermost scale it looks as if the two classes of nectaries were directly connected. The petiolar glands have perhaps become much more developed in the scales, so that the function of these latter is now wholly that of secreting honey.

\footnotetext{
1 Morini, Contributo all' anatomia ed alla fisiologia dei Nettarii Estranuziali, Mem. Accad. Bologna, I 886, vii.

${ }^{2}$ Reinke, Secretionsorgane, Prings. Jahrb., I876, p. I 25.

${ }^{3}$ Reinke, loc. cit.

^ Baillon, Étude générale des Euphorbiées, p. 230.
} 
The view of the evolution of the shoot of Hevea that suggests itself to the author is as follows. Originally the base of the shoot had one, two, or three non-nectariferous bud-scales such as occur now; the rest of the foliar organs were true foliage leaves arranged equidistantly along the axis. Assuming that their laminas gradually increased in size towards the middle of the shoots and then decreased, the lowest and highest leaves would in consequence be the smallest and the middle ones the largest-a condition often occurring in shoots. That of the Beech (Fagus sylvatica) is a case in point. Providing that the Hevea shoot had an upward tendency, as it has at the present day, the large median leaves would tend to overshadow the lower smaller ones, and thus render these latter to a great degree functionless as assimilating organs, and through disuse a gradual reduction in their laminas might follow. The nectaries on the petiolar apices still remaining would be the first to secrete. Viewing their service as one of attracting ants to keep off leaf-destroying insects, it would be an advantage to the plant to retain the nectaries on these retrograde leaf-structures, and further to increase their size and consequently their secretion, in order to protect the expanding foliage leaves, till their nectaries became functional. Thus gradually a condition which now occurs would be brought about.

The Beech shoot has a few scales at its base without any lamina, which may be comparable, though not homologous as they are stipules, to the non-nectariferous scales of Hevea; then come the foliage leaves increasing in size as far as the middle of the axis, and then diminishing towards the apex. There is a tendency in some of its shoots for the small lower leaves to wither and fall early. This may be partly due to their being shaded by the higher leaves, though this overshadowing is largely guarded against by the shoot as a rule having a horizontal direction, and as a consequence the leaf-blades are in one and the same plane. If the shoot, on the other hand, were inclined considerably to the vertical as in Hevea, then the middle leaves would shade the lower ones much more effectually. Such a shoot as that of the Rhododendron demonstrates this. It is obliquely erect and has the foliage leaves crowded together on its upper part, thus resembling the shoot of Hevea. The length of stem below the rosette of foliage leaves is not a single internode, but composed of several, the nodes of which in the young state were occupied by small leaves which have shrivelled and disappeared. These, being perhaps originally smaller than the middle leaves and thus subject to shade, now no longer persist as functional foliage leaves; they have most likely decreased still further in size, and now apparently serve as protective scales to the bud. Consequently as a rule in horizontal shoots the lowest foliage leaves are the smallest, or at any rate smaller than the middle ones; while in shoots inclined to the vertical the lowest leaves are the largest, because 
they represent probably the middle leaves of the primitive shoot, the lowest having ceased to act as foliage leaves.

The reason why in an ordinary shoot such as that of the Beech the middle leaves should generally be the largest is perhaps owing to the intensity of growth during development, first rising gradually to a maximum, then falling again till growth ceases. This would result in the first and last formed leaf-blades being the smallest.

The only other species of Hevea I have been able to examine is H. spruceana, Müll.-Arg., a very closely allied one. It possesses similar nectariferous scales.

\section{SUMMARY.}

I. Hevea brasiliensis possesses two kinds of extra-floral nectaries :-

(a) Small inconspicuous glands situated on the upper surface of the foliage leaves, where the three leaflets join the petiole (Fig. $3 n$ ).

(b) Large conspicuous glands borne on vestigial foliar structures'bud-scales' - which are situated on the shoot below the foliage leaves proper (Figs. I and $2 n s$ ).

2. The 'bud-scale' nectaries are a prominent feature of the young expanding shoot, and are functional till the foliage leaves are mature, when they wither and drop off. They are present in saplings, as well as in adult trees, but were not observed in seedlings.

3. Besides these nectariferous structures, one or more insignificant budscales without nectaries may be present at the base of the shoot (Figs. I and $2 s$ ).

4. The minute structure of the foliar and 'bud-scale' nectaries is the same. Each consists of a well-defined secretory epithelium with a thick cuticle. The original cells of this epithelium may be divided here and there by one or two tangential walls to form in places a two- or threelayered epidermis (Fig. 7). The nectar escapes by the bursting of the cuticle.

5. The two kinds of extra-floral nectaries are considered as homologous ; that is to say, the 'bud-scale' one may be regarded as a further development of what was at one time a petiolar nectary.

6. These nectariferous structures, occupying relatively the same position on the shoot as ordinary bud-scales, probably never had a protective function, but have been derived directly from what were once foliage leaves by the disappearance of the lamina and an increase in size of the nectary.

7. According to the usual view taken of the function of extra-floral nectaries, the 'bud-scale' glands may be looked upon as attracting ants to keep off insects injurious to the developing foliage. As soon as the foliage 
leaves mature, their own nectaries become functional, and the scale ones being no longer required wither and drop off.

8. This case of Hevea brasiliensis is the first striking instance recorded, as far as the author is aware, of bud-scales-cataphyllary leaves-serving solely as nectaries.

\section{POSTSCRIPT.}

Just on the completion of this paper a communication on the extrafloral nectaries of Hevea, read before the Academy of Sciences, Paris, on November 9, 1903, came to my notice. The article ${ }^{1}$ resulting from it in the corresponding number of the 'Comptes Rendus' deals wholly with the structure of the petiolar nectaries, and makes no reference whatsoever to the nectariferous bud-scales; hence the chief subject-matter of my paper is not in the least affected. The authors state that the number of individual glands composing the petiolar nectary of Hevea brasiliensis may vary between two and five, but is usually three. They point out that the secretory epidermis of the nectary is two-layered in places, and lay stress on the two following structural features: (I) the presence of a ring of lignified parenchyma in the interior of the raised border which surrounds the secretory surface of each gland; (2) the laticiferous tubes, occurring in fair abundance in the specialized parenchyma of the gland, either end just below the secretory epidermis, or even pass between the epidermal cells to the exterior.

J.P.

Cambridge, December, Igo3.

${ }_{1}$ Daguillon et Coupin, Sur les nectaires extra-floraux des Hevea, Comp. Rend. cxxxvii, No. 19, 1903, pp. 767-9. 
Annals of Botany.
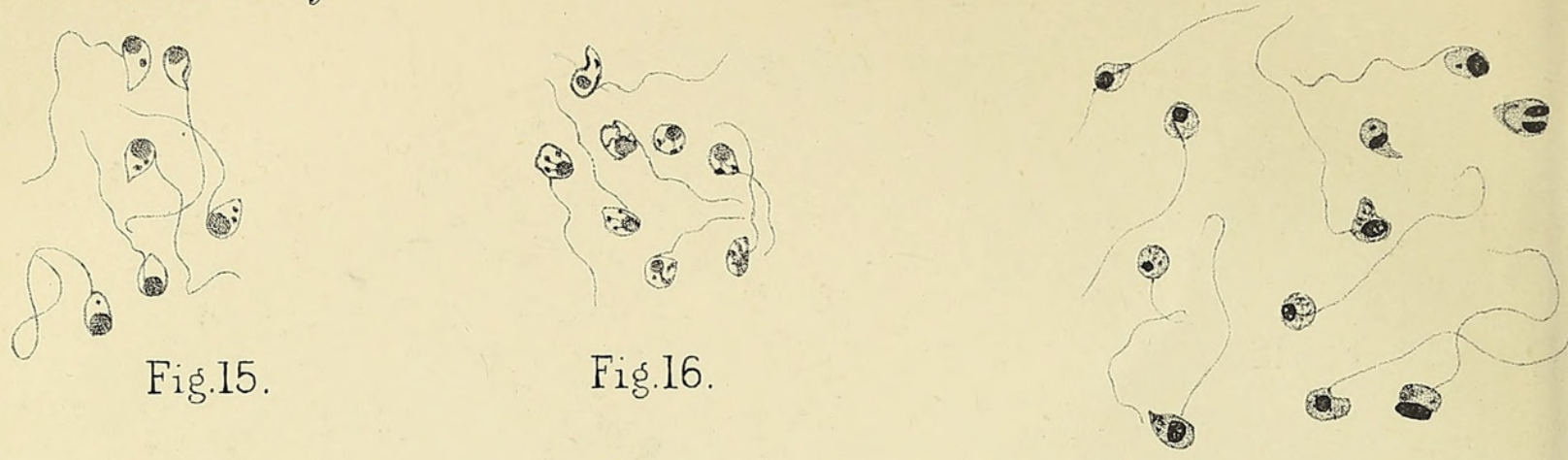

Fig.17.

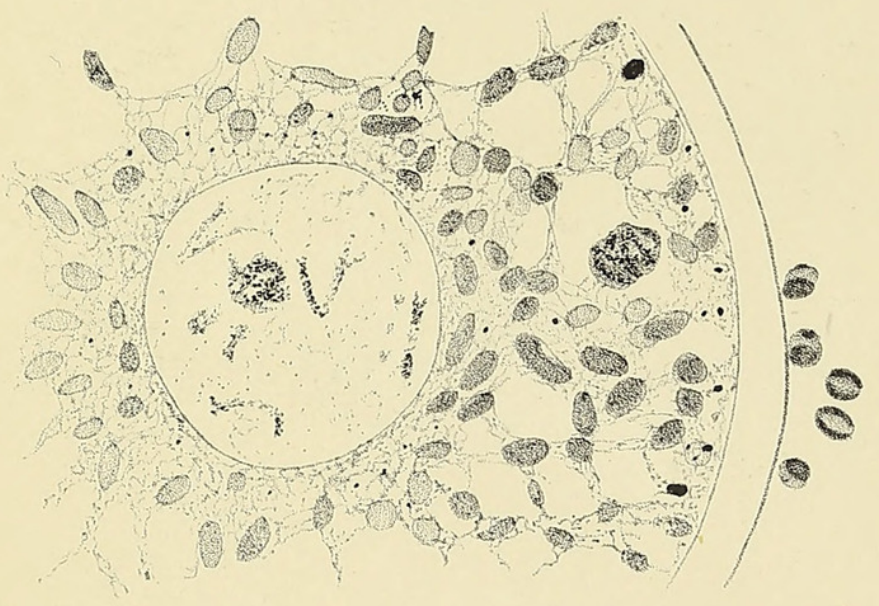

Fig. 20.
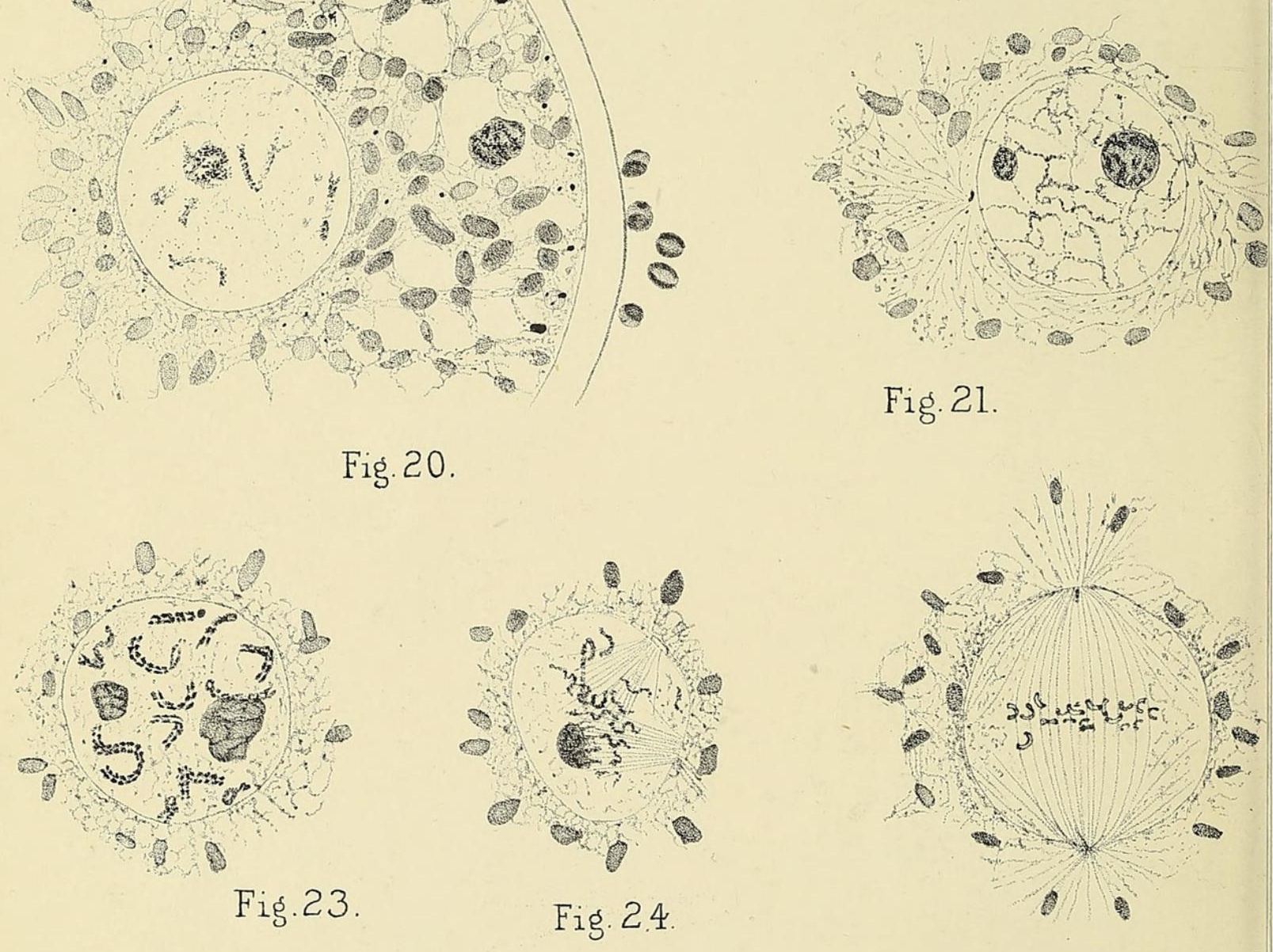

Fig. 21.

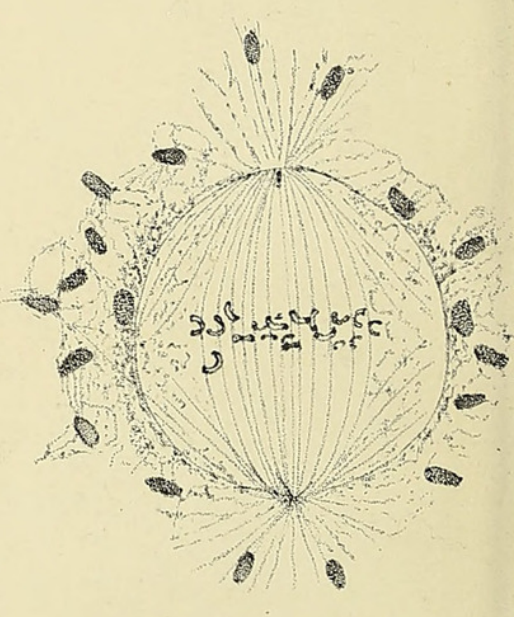

Fig. 25.

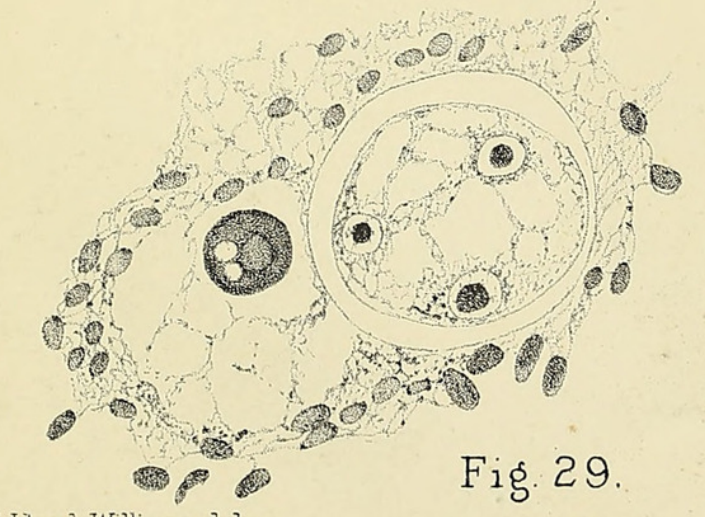

J. Lloyd Williams del.

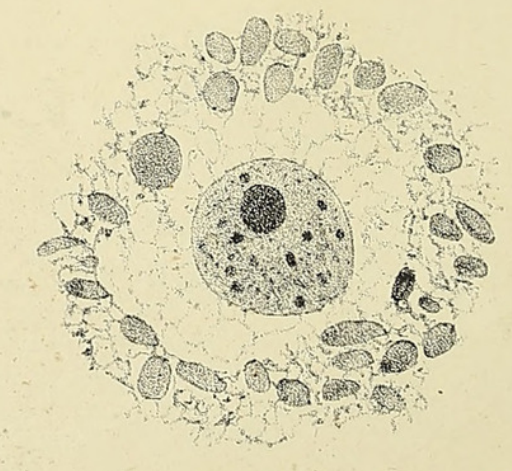

Fig. 30. 


\section{$2 \mathrm{BHL}$ Biodiversity Heritage Library}

Parkin, John. 1904. "The extra-floral nectaries of Hevea brasiliensis, Müll.- Arg. (the para rubber tree), an example of bud-scales serving as nectaries." Annals of botany 18, 217-225. https://doi.org/10.1093/oxfordjournals.aob.a088959.

View This Item Online: https://www.biodiversitylibrary.org/item/234469

DOI: https://doi.org/10.1093/oxfordjournals.aob.a088959

Permalink: https://www.biodiversitylibrary.org/partpdf/318756

\section{Holding Institution}

Smithsonian Libraries

\section{Sponsored by}

Biodiversity Heritage Library

\section{Copyright \& Reuse}

Copyright Status: Not in copyright. The BHL knows of no copyright restrictions on this item.

This document was created from content at the Biodiversity Heritage Library, the world's largest open access digital library for biodiversity literature and archives. Visit BHL at https://www.biodiversitylibrary.org. 